\begin{tabular}{lc}
\hline CURRENT & ISSN: 0973-4929, Vol. 13, No. (3) 2018, Pg. 464-470 \\
WORLD & Current World Environment
\end{tabular}

ENVIRONMENT

Journal Website: www.cwejournal.org

\title{
Biomass Carbon, Carbon Sequestration Potential and Soil Properties as Influence by Different Modules for Management of Chambal Ravines
}

\author{
AKHILESH SINGH*, S.K. VERMA, PRIYADARSHANI A. KHAMBALKAR, \\ SHASHI S. YADAV and SUNIL RAJPUT
}

Department of Soil Science and Agricultural Chemistry, College of Agriculture, RVSKVV, Gwalior.

\begin{abstract}
Abstarct
Erosion through ravines causes many problems on bank of Chambal River in Madhya Pradesh. It damages rangelands, croplands and infra-structures. Plantation of different fruit trees (Moringa oleifera, Amblica officinalis, Psidium guaijava, Ziziphuszezuba, Punica grantum, Annonasquamosa), forest/medicinal trees (Cenchr sciliaris, Azardirechtaindica, Pongamia pinnata, Albizialebbeck, Dalbergiasisso and Acacia nilotica) and some grasses (lemon grass, pamarosa, para and napier grass) under four management modules viz. $\mathrm{M}_{1}$ - diversified cropping system, $M_{2}$-Agri-horticultural, $M_{3}$-Horti-pastoral, $M_{4}$-Silvimedicinal and $M_{5}$-Silvi-pastoral were raised during 2012 at $3 \times 3 \mathrm{~m}$ spacing. Plants absorb carbon dioxide from the atmosphere by the process of photosynthesis and store the carbon $(C)$ as biomass. The highest biomass carbon was yielded in Module $M_{3}$, followed by $M_{2}, M_{5}$, $M_{4}$ and $M_{1}$, respectively. The average biomass carbon was found highest in grasses followed by fruit and forest trees. The study shows that the carbon sequestration in soil $(0-15 \mathrm{~cm})$ was found highest in $\mathrm{M}_{4}(0.45 \%)$ followed by $M_{5}(0.44 \%), M_{1}(0.36 \%), M_{2}(0.35 \%)$ and between depth $15-25 \mathrm{~cm}$ the soil sequestration was highest in $M_{1}$. The percent increase in soil carbon from 2012 to 2017 was highest in $M_{1}(0-15 \mathrm{~cm})$, while in depth $15-25 \mathrm{~cm} \mathrm{M}_{4}$ showed highest increase in soil carbon. Available nutrient status showed tremendous changes over initial value whereas available phosphorous showed decreasing trend under all modules after six years of studies.
\end{abstract}

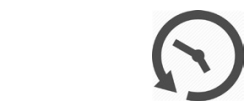

Article History

Received: 30 August 2018

Accepted: 19 December 2018

\section{Keywords}

Biomass;

Carbon Sequestration;

Ravine and

Soil properties.

CONTACT Akhilesh Singh $\longrightarrow$ akhileshsingh01@gmail.com Department of Soil Science and Agricultural Chemistry, College of Agriculture, RVSKVV, Gwalior.

\section{(c) (i)}

(c) 2018 The Author(s). Published by Enviro Research Publishers.

This is an Open Access article licensed under a Creative Commons license: Attribution 4.0 International (CC-BY).

Doi: http://dx.doi.org/10.12944/CWE.13.3.19 


\section{Introduction}

In recent centuries, the concentration of atmospheric $\mathrm{CO}_{2}$ has increased to $380 \mathrm{ppm}$, mainly due to anthropogenic activities. ${ }^{11}$ Forestation plays a very vital role in reducing $\mathrm{CO}_{2}$ through soil carbon sequestration. ${ }^{10}$ Carbon is found in all living organisms and is the main building block for life on earth. It is present in the soil organic matter, plants and animals, geologic deposits, atmosphere as carbon dioxide $\left(\mathrm{CO}_{2}\right)$ and dissolved in sea water.

There is a need to identify and utilize the different types of land use systems in dropping the atmospheric $\mathrm{CO}_{2}$ concentration and enhancing the carbon storage in the forestry and agroforestry systems. The importance of plantation, crops, forests (or trees) in carbon cycles is well recognized19 and forests a large sink of carbon. There is challenge to improve the carbon storage capacity of earthly vegetation through utilization of different land-use and land cover systems such as renewal of forests, silviculture and agroforestry. ${ }^{4}$ Agroforestry systems are very significant in the area currently under agriculture. Farmers depend on agricultural lands for their source of income, and the requirement for linking food production with environmental services. ${ }^{8}$

While the primal natural ecological systems characterize as major vegetation and soil $\mathrm{C}$ sinks, a substantial extent of this has already been lost particularly in underdeveloped and developing nations of the world. It is unlikely that these degraded areas such as ravines land will be converted to natural green cover. The need for transmuting these less utilized biomass land uses (such as ravine lands) to carbon-rich plantation of horticulture, forestry, agroforestry, and medicinal plants through different ravine management modules. In recent past major emphasis was given to management of agricultural systems for mitigating climate change effect through carbon sequestration. ${ }^{13}$ Establishing and handling perennial vegetation to increase $C$ sequestration is inexpensive compared to most other techniques, and these practices have least environmental and health risks. Perennial vegetation is more efficient than annual vegetation as it allocates a higher percentage of $\mathrm{C}$ to below-ground and often extends the growing season, ${ }^{13}$ so increasing $\mathrm{C}$ sequestration potential of systems even in future. ${ }^{15,12}$
Out of total available lands in India about $3.97 \mathrm{~m}$ comes under ravine, which is severely degraded form of lands. Protection of nearby productive lands is necessary from overexploitation and poor management. The unavailability of nutrient and moisture in the soils of ravine land severely affected vegetation of the area. The area experienced extreme weather conditions during summer as well as in winter with less rainfall, which make agriculture non-profitable in the region. Under these conditions, efficient nutrient and water management technologies required for sustainable production and livelihood to the farmers of ravine.

Impacts of different land use help to sequester carbon in degraded land, improve the groundwater table, land productivity, microclimate and livelihood options for farmers. Different land use modules help to recover ecological condition of ravine lands of Madhya Pradesh. ${ }^{2}$ Soil fertility, structures and water holding capacity of degraded soils will be enhanced by soil carbon sequestration which improved productivity and profitability. The greening of ravine lands also helps in protection of soil and increasing the water availability eroded gullies. The present study was performed to evaluate the plants biomass and carbon sequestration potentials under different modules of management of ravine.

\section{Materials and Methods}

The present study was conducted at university experimental site at the village Aisah of Morena district of M. P., near to the bank of Chambal river and is about $80 \mathrm{Km}$ from university head quarter. The location of project area is at Latitude 26040'40.84" N and Longitude 7806'29.21 E with altitude ranges 150 to $240 \mathrm{~m}$ above MSL.

The depth of soil varied from $30 \mathrm{~cm}$ to $>120 \mathrm{~cm}$ with sandy clay loam in texture. Physiographic position of the Morena District is central high land pathar. The slope gradient of the fields was mostly in between 0.1 to 8.0 per cent (very gently sloping to gently sloping). The problem of severe to very severe erosion is prominent because the area was mostly uncultivated during rainy season. Soil have almost medium to low water holding capacity. 
The study conducted to estimate carbon sequestration potentials under different land use system in ravenous watersheds. The experiment was started during the year 2011-12. The five module $M_{1}$-Diversified cropping system, $\mathrm{M}_{2}$ - Agri-horti module, $\mathrm{M}_{3}$-Horti Pastoral module, $\mathrm{M}_{4}$ - Silvi-Medicinal Module, $\mathrm{M}_{5}$-Silvi-Pastoral, were developed for sustainable management of Chambal ravines. The partially land terracing and cleaning a layout of the experimental plot was laid down in 15 blocks of $60 \times 70$ meter each to accommodate five modules in three replications. Total gross area of an experimental site was 20.475 ha. Planting geometry consist two main plots with area $4200 \mathrm{~m}^{2}$ with 300 plants per plot. Six species of fruits trees (Drumstick, Aonla, Ber, Guava, Custard apple and pomegranate ) and ten species of silvi-medicinal (Neem, Arjuna, Mahua, Gugul, Karanj, Babool, Teak, Siras, Khamer, Seasham) were transplanted in pits of $30 \times 30 \times 45 \mathrm{~cm}$.

The organic carbon content of soil was estimated, ${ }^{21}$ and biomass under different five modules was estimated with the help of carbon analyzer. Similarly available nitrogen, ${ }^{20}$ available phosphorus, ${ }^{16}$ available potassium, ${ }^{14}$ and percent aggregates (> 500 $\mathrm{mm}$ ) of soil were estimated. ${ }^{22}$ The activity involved in measurement of tree parameters from different modules to obtain single tree weights, quantification of the total standing biomass stock of the modules and ultimately estimation of standing stock of biomass per ha. The parameters of tree were measured including; diameter (dbh), bole height, tree height and crown diameter/width.

\section{Estimation of Biomass}

It is hardly ever possible to measure all biomass of an area by destructive sampling. Some form of allometry is used to calculate the biomass of separate plants to measurable properties such as its stem diameter. The plant having diameter at breast height greater than or equal to $2 \mathrm{~cm}$ $\mathrm{DBH}$ would be used for above ground biomass estimation of vegetation.

\section{Biomass Carbon in Plants per Year}

The trees, planted in tropical climates, especially in agroforestry, help to sequester atmospheric $\mathrm{CO}_{2}$ approximately @ 50 pounds of $\mathrm{CO}_{2}$ tree $^{-1}$ year $^{-1}$. Most conditions may affect the rate of carbon sequestration in plant, i.e., their growth characteristics, the density of the tree's wood, and the conditions for plant growth where it planted. Carbon sequestration was highest in the early ages, between 20 to 50 years. ${ }^{1}$ To calculate the quantity of biomass carbon stored in a given plant, the annual biomass carbon sequestration rate was obtained by dividing plant age. The process consisted determination of:

1. Total (green) weight of the tree.

2. Dry weight of the tree.

3. Weight of carbon in the tree.

4. Weight of carbon dioxide sequestered in the tree 5. Weight of $\mathrm{CO}_{2}$ sequestered in the tree per year

\section{Total (green) Weight of the Plant}

To calculate the weight of a plant following formula used $^{1}$

$\mathrm{W}=$ weight of the plant (grams), $\mathrm{D}=$ Diameter of stem $(\mathrm{cm}), \mathrm{H}=$ Height of the plant (meter).

If $\mathrm{D}<11$ then,

$W=0.25 D^{2} H$

If $D>11$ then,

$W=0.15 D^{2} H$

The given two equations could represent an average of all the plant species equations. The coefficient (e.g. 0.25) varied, and $\mathrm{D}^{2}$ and $\mathrm{H}$ could be raised to exponents just above or below depending on plant species. The weight of root system about $20 \%$ weight of tree above ground. Hence, to calculate the total green weight of the plant, the above-ground weight of the tree multiplied by $120 \%$.

\section{Dry Weight of the Tree ${ }^{19}$}

To determine the dry weight of the tree, the weight of the plant multiplied by $72.5 \%$. This is calculating by taking all species into account, having average tree dry matter $72.5 \%$ and moisture $27.5 \%$.

\section{Carbon Weight in the Tree}

The tree's total volume generally contain $50 \%$ of average carbon. ${ }^{18}$ Therefore, the weight of carbon in the plant is 50 per cent of plants dry weight. 
Weight of $\mathrm{CO}_{2}$ Stored in the Tree

$\mathrm{CO}_{2}$ having one molecule of Carbon and 2 molecules of Oxygen. The atomic weight of Carbon is 12.001115, whereas Oxygen's atomic weight is 15.9994 . Hence the estimated weight of $\mathrm{CO}_{2}$ is, $\mathrm{C}+2^{\star} \mathrm{O}=43.999915$; and $\mathrm{CO}_{2}$ : $\mathrm{C}$ ratio is $43.999915 / 12.001115=3.6663$.

Hence, the weight of $\mathrm{CO}_{2}$ stored in the plant is estimated, by multiplying 3.6663. The weight of $\mathrm{CO}_{2}$ sequestered in the plant per year $=$ Weight of $\mathrm{CO}_{2}$ stored in plant/ age of plant.

\section{Results and Discussion}

\section{Bio-Mass Carbon in Different Modules}

Since the biomass in plants developed with increasing age, delaying harvesting to maturity may help in development of huge carbon sink. The bio-mass carbon of various modules was calculated for the year 2012-13, 2013-14, 2014-2015, 2015-16 and 2016-17. The bio-mass carbon was highest in Horti-Pastoral module $\left(\mathrm{M}_{3}\right)$ followed by Silvi-Pastoral Module $\left(\mathrm{M}_{5}\right)$, Agri-Horti module $\left(\mathrm{M}_{2}\right)$, Silvi- Medicinal Module $\left(\mathrm{M}_{4}\right)$ and diversified cropping system $\left(M_{1}\right)$ during 2016-17, while Horti-Pastoral module $\left(M_{3}\right)$ followed by diversified cropping system $\left(M_{1}\right)$, Agri-Horti module $\left(\mathrm{M}_{2}\right)$, Silvi-Pastoral Module $\left(\mathrm{M}_{5}\right)$, and Silvi-Medicinal Module $\left(\mathrm{M}_{4}\right)$ in 2012-13. The highest change in biomass carbon is 89 per cent in module $M_{5}$ followed by 85 per cent in $M_{3}$, 84 per cent in $M_{4}$ and 80 per cent in $M_{2}$. (Fig.1). A mix of agro forestry with crop fields is a promising option to enhance $\mathrm{C}$ sequestration in soils. The tree components in agroforestry systems can be important sinks of atmospheric carbon due to their fast growth and high productivity. ${ }^{9}$

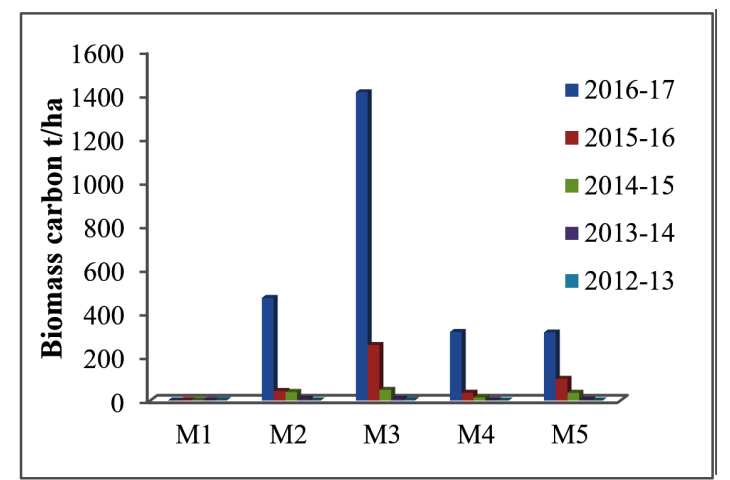

Fig. 1 Biomass Carbon in Different Modules of Ravine Management
Biomass Carbon in Different Trees / Plants, Grasses and Crops

The average biomass carbon was highest in Fruit trees followed by silvi, medicinal, crops, forest trees and grasses plants during 2012-13 to 2016-17 (Fig.2.). This is basically due to highest growth as well as biomass production which increase biomass carbon production compare to other plants, crops and grasses. ${ }^{7}$ Noticeable differences were recorded under tree plants. The low rate of biomass carbon in early ages of plants were recorded. Similarly, increase in biomass carbon after $6^{\text {th }}$ year of study were observed under all modules may be due to the fact that we used diameters at Brest height $(\mathrm{DBH})$ for estimation of above ground biomass, given in Eq (1). However, out of total 16 trees 10 trees a uniform pattern of yearly biomass C-storage and lower storage of carbon over time. Drumstick in all modules showed a continuous increase in C-storage with the age. The data suggested that planting the fast-growing species in the degraded land was an effective choice in terms of carbon sequestration. ${ }^{5}$ The C-storage pattern of Guava, Pomegranate, Mahua, Adusa custard apple and guggle exhibiated a very slow rate of growth and minimum biomass carbon accumulation at the end of study.

\section{Carbon Sequestration in Soil}

At the end of sixth years result indicated that there was significant enrichment in soil organic carbon content given in table 1 under various management modules from initial level of organic carbon which was just $0.11-0.12 \%$ now came to the 0.30 to $0.35 \%$ in different management modules in surface soil. During first year it was maximum in $M_{1}$ and $M_{5}$ but there was more improvement in silvi-pastoral

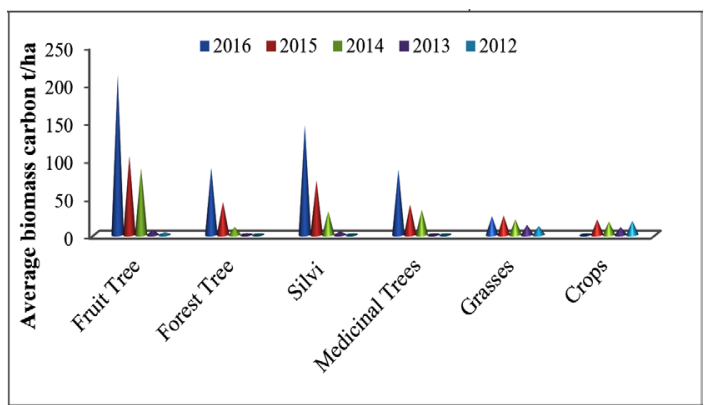

Fig. 2 Average Biomass Carbon Produced by Different Types of Tree, Grasses and Crops 
Table 1: Carbon Sequestration in Soil under different modules.

\begin{tabular}{|c|c|c|c|c|c|c|c|c|c|c|}
\hline \multirow{3}{*}{$\begin{array}{l}\text { Management } \\
\text { module }\end{array}$} & \multicolumn{8}{|c|}{ Organic Carbon in Soil (\%) } & & \\
\hline & \multicolumn{2}{|c|}{$2012-2013$} & \multicolumn{2}{|c|}{$2013-2014$} & \multicolumn{2}{|c|}{$2014-2015$} & \multicolumn{2}{|c|}{$2015-2016$} & \multicolumn{2}{|c|}{$2016-2017$} \\
\hline & $0-15$ & $15-25$ & $0-15$ & $15-25$ & $0-15$ & $15-25$ & $0-15$ & $15-25$ & $0-15$ & $15-25$ \\
\hline M1 & 0.26 & 0.22 & 0.35 & 0.32 & 0.38 & 0.34 & 0.41 & 0.36 & 0.40 & 0.35 \\
\hline M2 & 0.23 & 0.18 & 0.34 & 0.29 & 0.36 & 0.30 & 0.43 & 0.30 & 0.43 & 0.34 \\
\hline М3 & 0.16 & 0.18 & 0.30 & 0.23 & 0.34 & 0.26 & 0.34 & 0.30 & 0.36 & 0.30 \\
\hline M4 & 0.22 & 0.23 & 0.33 & 0.31 & 0.36 & 0.33 & 0.70 & 0.30 & 0.65 & 0.33 \\
\hline M5 & 0.26 & 0.20 & 0.32 & 0.26 & 0.37 & 0.28 & 0.65 & 0.31 & 0.60 & 0.32 \\
\hline
\end{tabular}

Table 2. Changes in Soil Properties under Different Modules over Initial Status

\begin{tabular}{|c|c|c|c|c|c|c|}
\hline \multirow[t]{3}{*}{ Module } & \multirow{3}{*}{$\begin{array}{l}\text { pH } \\
8.52\end{array}$} & \multirow{3}{*}{$\begin{array}{l}\text { EC } \\
0.42\end{array}$} & \multicolumn{3}{|l|}{$\mathrm{Kg} / \mathrm{ha}$} & \multirow{2}{*}{$\begin{array}{c}\text { Aggregate } \% \\
(>500 \mu \mathrm{m})\end{array}$} \\
\hline & & & $\mathbf{N}$ & \multicolumn{2}{|c|}{ Initial (2012-13) } & \\
\hline & & & 90.2 & \multicolumn{2}{|c|}{ Final (2016-17) } & 14.37 \\
\hline$M_{1}$ & 8.42 & 0.52 & 137.9 & 5.33 & 375.2 & 16.54 \\
\hline$M_{2}$ & 8.42 & 0.49 & 150.4 & 4.04 & 328.0 & 18.64 \\
\hline$M_{3}^{2}$ & 8.35 & 0.43 & 112.8 & 3.90 & 292.6 & 24.87 \\
\hline$M_{4}^{3}$ & 8.31 & 0.47 & 100.3 & 3.50 & 287.8 & 32.41 \\
\hline$M_{5}^{4}$ & 8.48 & 0.49 & 0.37 & 125.4 & 4.08 & 37.45 \\
\hline
\end{tabular}

module $\left(\mathrm{M}_{5}\right)$ as time is increasing. This value would be increasing many folds in coming time due to increasing age of trees. The continuous buildup of organic carbon under different module may be due to the supply of organic matter in the form of plant, crop and grass residues through litter fall which naturally incorporated in the soil and increase the level of organic carbon. ${ }^{17}$

\section{Soil Properties}

The changes in soil physico-chemical properties (Table 2.) were recorded in different modules at the end of experiment (2017) over the initial (2012) status. Soil is slightly alkaline and do not show much variation related to soil $\mathrm{pH}$ and $\mathrm{EC}$ with time. Slight decrease in soil $\mathrm{pH}$ and increase in soil EC were recorded under all modules at the end of study.
Markedly buildup of organic carbon was recorded under all modules of ravine land experiment over initial status $(0.09 \%)$ and maximum value $(0.38 \%)$ recorded in diversified cropping system $\left(M_{1}\right)$. Soil nutrient status showed drastic changes over initial status of soil especially in soil available nitrogen. The available nitrogen showed increasing trend over initial status, similarly available potash showed both increase $\left(M_{1}\right)$ and decrease $\left(M_{4}\right)$ values under different modules. Available phosphorus decreased with time under all modules. The percent aggregates $(>500 \mu \mathrm{m})$ increased under all modules due to continuous plantation cover which reduce soil erosion and bind soil particles. Closer examination of changes in soil properties over time following establishment of different modules of tree species is necessary to know the mechanisms answerable 
for changes in the soil organic matter and nutrient availability $^{3}$ which in turn will contribute in the development of effective long term strategies to maintain soil quality and fertility. ${ }^{6}$

\section{Conclusion}

The ravine area is perhaps one of the most severest and susceptible ecosystem with severe on-site and off- site implications. Management of ravine through plantation of various tree species for both soil health management as well as increasing the livelihood options to farmers.

The biomass carbon accumulation in above ground was highest in horti-pastoral followed by Agri-horti and silvi-pastoral modules of management of Chambal ravine. The organic carbon in the soil of highly degraded lands of Chambal increased from its initial level in the all modules of management the highest in organic carbon from $0.09 \%$ to $0.38 \%$ recorded in the diversified cropping system modules.

The management of Ravine area contribute significantly to improving soil carbon sequestration, which will help in mitigating the impacts of climate change. The management of ravine through plantation of horticultural, agro-forestry, pastoral plants shows positive impacts on biodiversity, soil conservation and contributing to soil carbon sequestration.

\section{Acknowledgements}

Author's thankful to the Niche Area of Excellence, RVSKVV, Gwalior, Madhya Pradesh India. Author also thankful to the, Division of Education, Indian Council of Agricultural Research, New Delhi for their funding support and facility provided during the course of study.

\section{References}

1. Alexander Clark III, Joseph R. Saucier, and W. Henry McNab (1986). "Total-Tree Weight, Stem Weight, and Volume Tables for Hardwood Species in the Southeast," Research Division, Georgia Forestry Commission, January 1986. http://www. forestdisturbance.net/publications/GF\%20 RP60-Clark.pdf

2. Behari, B., Agarwal, R., Singh, A. K. and Banerjee, S. K., Vegetation development in a degraded area under bamboo based agroforestry system. Indian Forest., 2000, 126(7), 710-720.

3. Binkley D, Högberg P (1997) Does atmospheric deposition of nitrogen threaten Swedish forests?. Forest Ecology and Management 92, 119-152.

4. Canadell JG, Raupach MR (2008) Managing forests for climate change mitigation. Science 320: 1456-1457.

5. Chen Y., Liu Z., Rao X., Wang X., Liang C., Lin Y., Zhou L., Cai Xi-an and Fu S. (2015). Carbon Storage and Allocation Pattern in Plant Biomass among Different Forest Plantation Stands in Guangdong, China
Forests, 6, 794-808.

6. Chirino I, Leo Condron A, Roger McLenaghenA and Murray Davis B. (2010) Effects of plantation forest species on soil properties Ivan. 19th World Congress of Soil Science, Soil Solutions for a Changing World 1 - 6 August 2010, Brisbane, Australia.

7. Devine W. D., Footen P.W., Harrison R.B., Terry T. A., Harrington C A., Holub S.M., and Gould P. J.(2013). Estimating Tree Biomass, Carbon, and Nitrogen in Two Vegetation Control Treatments in an 11-YearOld DouglasFir Plantation on a Highly Productive Site. Res. Pap. PNW-RP-591. Portland, OR: U.S. Department of Agriculture, Forest Service, Pacific Northwest Research Station. 29 p.

8. Garrity DP (2004) Agroforestry and the achievement of the millennium development goals. Agroforestry System 61: 5-17.

9. Gupta R. K., Vijay Kumar, Sharma K.R., Singh T. B., Singh G. and Mir G. (2017) Carbon Sequestration Potential through Agroforestry: A Review. Int.J.Curr.Microbiol.App.Sci 6(8): 211-220.

10. Hunter MD (2001) Effects of elevated atmospheric carbon dioxide on insect- 
plant interactions. Agricultural and Forest Entomology 3 (3), 153-159

11. IPCC, 2007: Climate Change 2007: Impacts, Adaptation and Vulnerability. Contribution of Working Group II to the Fourth Assessment Report of the Intergovernmental Panel on Climate Change, M.L. Parry, O.F. Canziani, J.P. Palutikof, P.J. van der Linden and C.E. Hanson, Eds., Cambridge University Press, Cambridge, UK, 976pp

12. Jose, S. 2009. Agroforestry for ecosystem services and environmental benefits: an overview. Agroforestry Systems, 76: 1-10.

13. Morgan, J. A., Follett, R. F., Allen L. H., Grosso, S. D., Derner, J. D., Dijkstra, F., Franzluebbers, A., Fry, R., Paustian, K. and Schoeneberger, M. M. 2010. Carbon sequestration in agricultural land of the United States. J. Soil Water Conserv, 65: 6A-13A.

14. Muhr, G.R, Datta, N.P., Sankara subramoney, H., Leley, V.K. and Donahue, R.L. (1965). Soil testing in India. 2nd Ed. USAID Mission to India, New Delhi (India)

15. Oelbermann, M., Voroney, R. P., Kass, D. C. L. and Schlonvoigt, A. M. 2006. Soil carbon and nitrogen dynamics using stable isotopes in 19- and 10-yr old tropical agroforestry systems. Geoderma, 130: 356-367.

16. Olsen, S.R., Cole, C.V., Watnbe, F.S. and
Dean, L.A. (1954).Estimation of available phosphorus in soil by extraction with sodium bicarbonate.U.S.D.A. Circ., 939.

17. Russell A. E., Raich J. W., Fisher R. F., and Valverde-Barrantes O.J. (2007). Tree Species Effects on Soil Properties in Experimental Plantations in Tropical Moist Forest. Soil Science Society of America,71 (2007): 1389, doi:10.2136/ sssaj2006.0069

18. Scott DeWald, Scott Josiah, and Becky Erdkamp (2005). "Heating With Wood: Producing, Harvesting and Processing Firewood," University of Nebraska - Lincoln Extension, Institute of Agriculture and Natural Resources, March 2005. http://www.ianrpubs. unl.edu/epublic/live/g1554/build/g1554.pdf

19. Singh R, Lal M (2000) Sustainable forestry in India for carbon mitigation. Current Science 78: 563-567.

20. Subbiah, B.V. and G.L., Asija(1956).A rapid procedure for the determination of available nitrogen in soils. Curr. Sci., 25: 259-260.

21. Walkley, A. and Black, C.A. (1934). Estimation of organic carbon by chromic acid titration method. Soil Sci., 37: 29-38.

22. Yoder, R.E. (1936). A direct method of aggregate analysis of soils and a study of the physical nature of erosion losses. J. Am. Soc. Agron., 28: 337-351. 